\title{
Clinical Features of Mycetoma and the Appropriate Treatment Options
}

\author{
Pooja Agarwal (D) \\ Ashish Jagati \\ Santoshdev P Rathod \\ Kirti Kalra \\ Shefali Patel \\ Malay Chaudhari
}

Department of Dermatology, Smt. SCL Hospital, Smt. N.H.L. Municipal Medical College, Ahmedabad, Gujarat, India
Correspondence: Kirti Kalra

Department of Dermatology, Smt. SCL Hospital, Smt. N.H.L. Municipal Medical College, OPD Room No. 16, Ahmedabad, Gujarat, India

Tel +9l 9416917766

Email kirtidudeja69@gmail.com

\begin{abstract}
Mycetoma is a chronic, suppurative and debilitating granulomatous infection seen mainly in tropical and subtropical areas and is now declared as a neglected tropical disease by the World Health Organization. The clinical diagnosis is usually characterized by a classical triad of localized swelling, underlying sinus tracts, and production of grains or granules, but unusual presentations are also seen. It is classified into eumycetoma caused by the fungus, and actinomycetoma caused by the bacteria. The clinical presentation of both is almost similar and a definite diagnosis is essential before starting the treatment as it differs for both. Surgical debulking followed by a prolonged course of medical therapy now forms the mainstay of treatment due to the long course of the disease and suboptimal response. This review focuses on the various usual as well as unusual clinical presentations of mycetoma, established treatment regimens as well as recent changes in the mode of administration of drugs and newer drugs for mycetoma.
\end{abstract}

Keywords: actinomycetoma, eumycetoma, Madura foot, treatment

\section{Introduction}

Recently, World Health Organization (WHO) has recognized mycetoma to be a "neglected tropical disease" as the disease has not received much attention despite the great medical and financial burden. It is a chronic infection that affects the skin, and subcutaneous tissue. In neglected cases, even bone involvement may be seen. Though the disease is found worldwide, it is more prevalent in the tropical and subtropical regions, popularly known as the "Mycetoma Belt" ( $30 \mathrm{~N}$ to $15 \mathrm{~S}$ latitude). ${ }^{1}$ The disease has been described as early as in the ancient Indian scriptures (Atharva Veda). ${ }^{2}$ The various nomenclatures include "Anthill foot" and "Madura foot". 2 It was only when the etiology was confirmed to be fungal, the word "mycetoma" was proposed by Carter. ${ }^{3}$ Later when both bacterial and fungal organisms were found to be causing mycetoma, the formal classification into Maduramycosis and Actinomycosis was recognized.

Actinomycotic mycetoma is caused by aerobic species of actinomycetes. The most common causative organisms are Nocardia Brasiliensis, Actinomadura Madurae, Actinomadura Pelletieri, and Streptomyces Somaliensis. ${ }^{1}$ Eumycotic mycetoma, as the name suggests, is associated with a variety of fungi, the most common of which is Madurella Mycetomatis. ${ }^{1}$

\section{Review Methodology}

The primary objective of this study was to review the various clinical presentations and the treatment options of mycetoma. We searched the MEDLINE database 
(PUBMED) with the keywords "Mycetoma" in the timeline of the last 5 years and 320 relevant studies appeared during the search.

Inclusion criteria: The inclusion criteria of this study were studies with clinical features and/or treatment options of mycetoma. The abstracts, as well as the full text of the studies were scholarly appraised and 24 studies, were found which met our inclusion criteria. These included 8 case reports, 6 review articles, 3 case series, 2 symposiums, 2 research articles, 1 original article, 1 short report and 1 chart review-based case series.

Exclusion criteria: Studies with epidemiology, laboratory diagnosis and holistic approach towards mycetoma were excluded from the review process.

\section{Clinical Presentation of the Disease Portal of Entry}

The causative organism enters the skin through some minor, often unnoticed trauma. As the incubation period is long and variable (3 months - many years), many patients do not distinctly remember the history of trauma when they present to a clinician. ${ }^{1}$

\section{Gender Predilection}

Males are affected more commonly (M:F=3:1), probably due to their greater exposure to pathogens during their work like agricultural fieldwork, etc. It has also been speculated that the female hormones, progesterone and estradiol might be having some inhibitory effect on the growth of the microorganisms, hence the greater frequency of disease in men. ${ }^{4,5}$

\section{Clinical Features}

Lower extremity is most commonly involved with the most common site being the foot. The next most common site is the hand (right more often than left) and other sites include the head and neck, chest, shoulder, and arms. ${ }^{6}$ Rare sites for eumycetoma include the abdominal wall, face involving the bones, paranasal sinuses, orbit or eyelid, and genital involvement of the vulva or the scrotum. ${ }^{7}$ Actinomycetoma is found more often on the chest or abdominal wall as compared to the extremities and mycetoma involving both limbs has also been reported. ${ }^{7}$

As the mycetoma involves mainly the skin and the subcutaneous tissue, the presentation is usually the classical triad of a painless, indurated subcutaneous mass giving a woody hard feel, multiple discharging sinuses, and presence of grains in the purulent or seropurulent discharge ${ }^{6}$

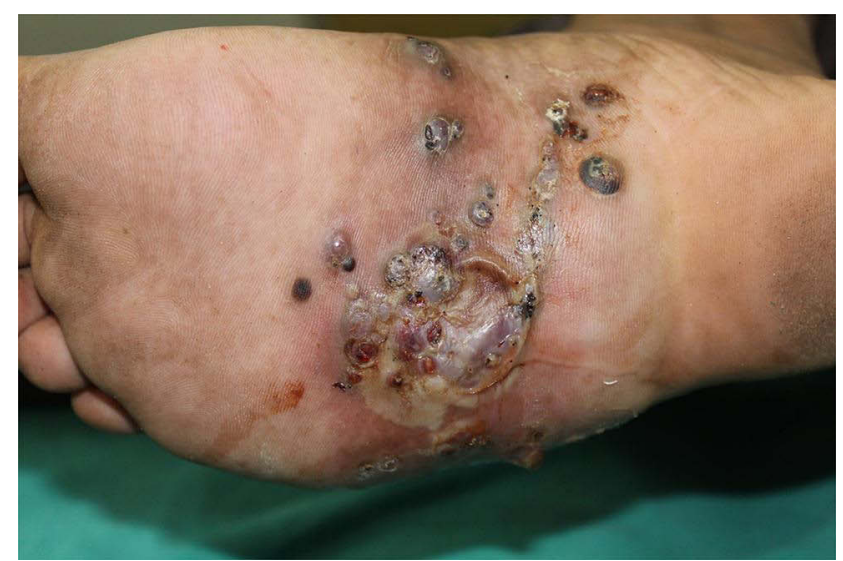

Figure I Classic triad of mycetoma with woody hard swelling, discharging sinuses and grains.

(Figure 1). These grains are the colonies of the causative microorganisms, hence differ in color, size, and consistency according to the etiology. ${ }^{6}$ Sometimes however, this classical triad may not be present and it becomes difficult to diagnose the disease. ${ }^{6}$ Instead of the usual indurated swelling, sometimes a soft and lobulated or rarely a cystic swelling may be seen. ${ }^{7}$ Rare presentations which have been observed include a verrucous plaque ${ }^{6}$ or a painless firm swelling over sole without any discharging sinuses in absence of a prior history of trauma or bare-footing walking. ${ }^{8}$

The initial lesion at the site of injury is usually a small papule that slowly progresses to a painless nodule. An abscess or an ill-defined area of induration may also be seen as the initial lesion sometimes. ${ }^{7}$ As the lesion progresses, pustules appear which subsequently rupture with a purulent or seropurulent discharge containing grains. ${ }^{8}$ These pustules and nodules increase in size and rupture over the skin surface as well as along the fascial planes, leading to the spread of disease. ${ }^{7}$ Sinuses form as the disease penetrates deeper and these are usually connected also. Alternating phases of disease activity and healing lead to the presence of fresh as well as healed sinuses at the same time, which is very characteristic for mycetoma. ${ }^{7}$ The overlying skin becomes smooth, stretched, and shiny with areas of hypo- or hyper-pigmentation and is fixed to the underlying structures. ${ }^{8}$ Rarely, there may be an increase in sweating and raised local temperature over the lesion which is probably due to sweat gland hyperplasia and increased vascularity due to inflammation, respectively. $^{7}$

Grains which are seen in the discharge during the active phase of the disease, are the colonies of the causative 
microorganisms which are encapsulated in a cement-like material along with melanin and other substances. ${ }^{7}$ These coating materials are believed to protect against the host defense mechanisms as well the therapies with antimicrobials and antifungals. ${ }^{7}$ Most of the time, these grains are easily visible to the naked eyes and their color is usually indicative of the causative organism as black/dark grains are always diagnostic of eumycetoma, while red/pink grains are diagnostic of actinomycetoma. White to pale yellow grains may be seen in both eumycetoma and actinomycetoma. The consistency of grains also varies from soft to firm and hard, depending upon the species. Usually, the grains are soft, but those due to Scedosporium somaliensis and Madurella mycetomatis can be quite hard. ${ }^{1}$ The usual grain color according to the etiological agents are given in Table 1 (though the list of etiological fungi is exhaustive, only the common ones are included in the table).

Despite the aggressive clinical presentation, the condition is usually painless. ${ }^{7}$ This absence of pain has been speculated to be the result of some anesthetic substances produced by the organisms. ${ }^{8}$ In the later stages of the disease, the nerve damage as a result of entrapment in the intense fibrous tissue reaction or decreased vascular supply leads to an absence of any pain sensation. ${ }^{7}$ Pain has only been reported in $15 \%$ of patients and is attributed to

Table I Color of Grains and Implicated Causative Species

\begin{tabular}{|l|l|}
\hline Color of Grain & Species \\
\hline \multicolumn{1}{|c|}{ Eumycetoma } \\
\hline Black to brown & $\begin{array}{l}\text { Madurella Mycetomatis, Trematosphaeria Grisea } \\
\text { (Formerly Madurella Grisea), Falciformispora } \\
\text { Senegalensis (Formerly Leptosphaeria Senegalensis), } \\
\text { Curvularia Lunata, Exophiala Jeanselmei, Exophiala } \\
\text { Oligosperma, Madurella Fahalii, Madurella } \\
\text { Pseudomycetomatis, Madurella Tropicana, } \\
\text { Phialophora Verrucose, Scytalidium Dimidiatum }\end{array}$ \\
\hline Yellow & Neotestudina Rosatii \\
\hline $\begin{array}{l}\text { White to pale } \\
\text { yellow }\end{array}$ & $\begin{array}{l}\text { Acremonium Spp. } \\
\text { Fusarium Spp. } \\
\text { Scedosporium Apiospermum }\end{array}$ \\
\hline \multicolumn{1}{|c|}{ Actinomycetoma } \\
\hline White to yellow & $\begin{array}{l}\text { Nocardia Species } \\
\text { Actinomadura Madurae } \\
\text { Streptomyces Somaliensis }\end{array}$ \\
\hline Red to pink & Actinomadura Pelletieri \\
\hline
\end{tabular}

superimposed bacterial infections or imminent rupture of a new sinus over the skin surface. ${ }^{8}$

Mycetoma is usually localized but in neglected cases, slow spread along the fascial planes may occur with subsequent involvement of the underlying structures like ligaments, muscles and, bones. ${ }^{7}$ Involvement of muscles and bones makes the disease more resistant to treatment and may present as osteomyelitis also. In rare cases where mycetoma affects the tissue over the back, there may be vertebral compression leading to neurological manifestations. ${ }^{6}$ Nerves and tendons are only rarely affected in mycetoma and even when it occurs, it is very late in the disease, reasons being unknown. Hence, even in long-standing cases of mycetoma, trophic changes are seen infrequently. ${ }^{7}$ As a consequence of the chronic inflammatory process in mycetoma, the arterial blood flow is increased to the site which may further explain the lesser frequency of trophic changes. ${ }^{7}$ Dilated tortuous veins resembling varicose veins may develop around and proximal to a massive mycetoma of long duration and are a compensating mechanism to accommodate the increased venous return. ${ }^{7}$

\section{Lymphatic and Hematological Spread}

In most of the patients, the regional lymph nodes are not significantly enlarged and are shotty. An enlarged regional lymph node is most commonly a result of secondary bacterial infection. ${ }^{7}$ However, the genuine lymphatic spread of mycetoma may also occur and sporotrichosislike lesions along lymphatics have been reported. Metastatic lesions can occur at distant lymph nodes which are seen more commonly in actinomycetoma. These distant lymph nodes may suppurate thus causing difficulty in diagnosis. ${ }^{7}$ Another reason for lymphatic spread is multiple inadequate surgeries. ${ }^{9}$ Although rare, hematological spread has also been described. ${ }^{7}$

The clinical presentation of both eumycetoma and actinomycetoma are almost identical, but the differentiation is important as the management and prognosis of both are completely different. Eumycetoma grows slowly and remains well encapsulated for a longer time as compared to actinomycetoma which grows rapidly and is more destructive. ${ }^{7}$ The differences are summarized in Table 2.

In general, due to the localized nature of the infection, constitutional disturbances are not seen. However, malaise and fever may be seen due to secondary bacterial infection. Anemia, immunosuppression and, cachexia may occur due to the chronicity of the disease in late neglected mycetoma. ${ }^{7}$ 
Table 2 Clinical Differentiation Between Eumycetoma and Actinomycetoma

\begin{tabular}{|c|c|c|}
\hline Feature & Eumycetoma & Actinomycetoma \\
\hline $\begin{array}{l}\text { Etiological } \\
\text { agent }\end{array}$ & Fungus & Bacteria \\
\hline Site & $\begin{array}{l}\text { Extremities, most } \\
\text { commonly foot } \\
\text { Trunk and head } \\
\text { involvement almost nil }\end{array}$ & $\begin{array}{l}\text { Most commonly on foot } \\
\text { Trunk and head } \\
\text { involvement may be seen }\end{array}$ \\
\hline $\begin{array}{l}\text { Progression } \\
\text { Lesions }\end{array}$ & $\begin{array}{l}\text { Slow } \\
\text { Well-encapsulated } \\
\text { Clear margin } \\
\text { Less inflammatory } \\
\text { Less destructive }\end{array}$ & $\begin{array}{l}\text { Rapid } \\
\text { Diffuse } \\
\text { Margins not very clear } \\
\text { More inflammatory } \\
\text { More destructive }\end{array}$ \\
\hline Sinuses & Few & Many \\
\hline Grains & $\begin{array}{l}\text { Usually black } \\
\text { Pale grains may be seen } \\
\text { Never red }\end{array}$ & $\begin{array}{l}\text { Usually pale yellow to white } \\
\text { Red grains may be seen } \\
\text { Never black }\end{array}$ \\
\hline $\begin{array}{l}\text { Underlying } \\
\text { structures }\end{array}$ & $\begin{array}{l}\text { Bone invasion is late } \\
\text { Multiple punched out } \\
\text { lytic lesions on } \\
\text { a radiograph }\end{array}$ & $\begin{array}{l}\text { Earlier invasion of bones } \\
\text { Both osteolytic and } \\
\text { osteosclerotic lesions on } \\
\text { radiograph }\end{array}$ \\
\hline
\end{tabular}

Note: Data from Relhan et al. ${ }^{\prime}$

\section{Treatment of Mycetoma}

As the diagnosis of mycetoma is usually overlooked in the initial stages, the late detection of the disease with gradual progression poses a great challenge to the treating physician and requires a multidisciplinary approach. In recent times, the treatment of mycetoma has taken a new insight as now systemic antimicrobials along with surgical debulking of the larger lesions are considered the core of mycetoma management. As the causative agents of mycetoma belong to two different families with completely different therapies, confirmation of the diagnosis is essential before commencing any treatment (Figure 2).

\section{Treatment of Actinomycetoma}

Actinomycetoma usually shows a good therapeutic response to systemic antibiotics. To date, co-trimoxazole (TMP-SMX) forms an integral part of actinomycetoma management and is considered a gold standard. It is preferred to use more than one drug along with it in combination to increase the response as well as prevent the development of resistance. The various standard regimes which are being used for the treatment of actinomycetoma are summarized in Table 3. Other drugs tried in conjunction with co-trimoxazole (TMP-SMX) are dapsone, netilmycin, DA -7867 (an experimental oxazolidinone; tried in vivo against $N$. brasiliensis). ${ }^{4}$ Oral linezolid (600mg twice a day) along with TMP-SMX has been found to show a good clinical outcome, thus making a way to use oral treatment as a preferred modality for the convenience of patients. By reducing the expenses and burden of hospital stay, it has a potential for better patient compliance too. ${ }^{10}$ Irrespective of the treatment followed, the duration of the therapy always varies according to the clinical outcome which varies from an individual to another. In non-responders or those with allergies to the combination, TMP-SMX can be replaced by amoxicillinclavulanate or carbapenems such as imipenem or meropenem and amikacin can be replaced by netilmicin. ${ }^{11}$ During pregnancy, monotherapy with amoxicillin-clavulanate is considered to be the safest option. ${ }^{11}$

\section{Treatment of Eumycetoma}

Surgical debulking forms an essential part of the treatment for eumycetoma due to poor drug penetration through the fibrous encasement of the lesion. It reduces the mycetoma load and provides a better response to clinical therapy. Scrupulous surgical dissection with appropriate safety margin followed by a thorough examination of all the cavities and deep pockets of the damaged tissues and its systematic irrigation with iodine solution and hydrogen peroxide is necessary to destroy hyphae and grains that have been left behind. ${ }^{12}$

Previously ketoconazole (400-800 mg/day) used to be the mainstay of eumycetoma therapy but its potential hepatotoxicity has reduced its use. ${ }^{1}$ Nowadays itraconazole (400 mg/day) in 2 divided doses is considered to be the gold standard therapy, however, the response and duration of treatment vary amongst different patients. ${ }^{1}$ Terbinafine (250-500 mg/day) has shown limited efficacy when used alone, but can be used in combination with itraconazole.

Both voriconazole $(400 \mathrm{mg} /$ day) in 2 divided doses and posaconazole (200-800 $\mathrm{mg}$ /day) have shown good in-vitro activity but a longer duration of treatment and relative lack of studies regarding their response precludes their use.

Newer drugs fosravuconazole, a prodrug of ravuconazole and Isavuconazole have shown promising results in in-vitro studies and are being clinically assessed in a double-blind clinical trial on eumycetoma. ${ }^{13}$

Echinocandins and amphotericin B, though useful in other deep fungal infections have poor in-vitro activity 


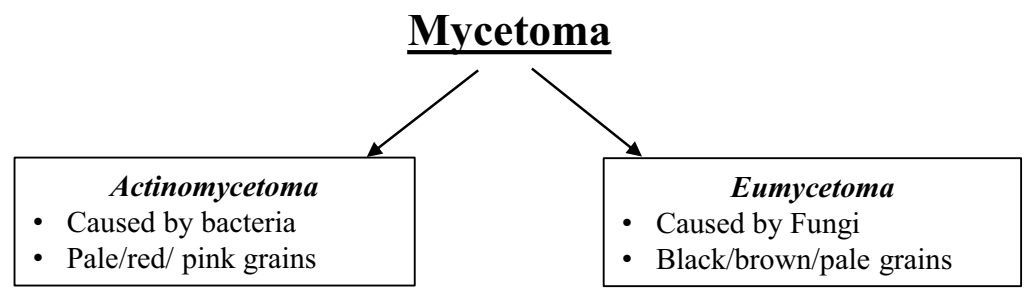

\section{Clinical Features}

\section{Classical Triad}

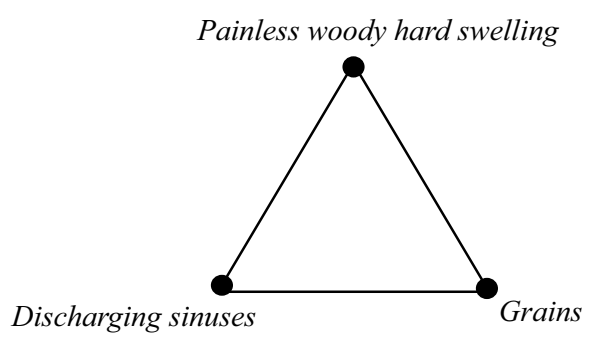

\section{Stages of Development}

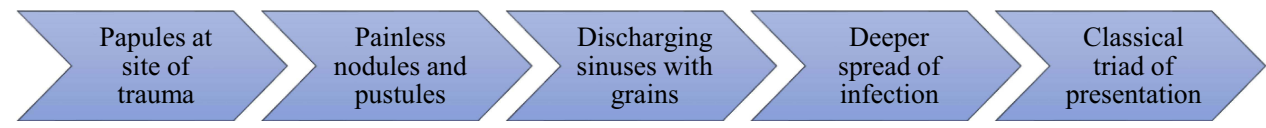

\section{Treatment}

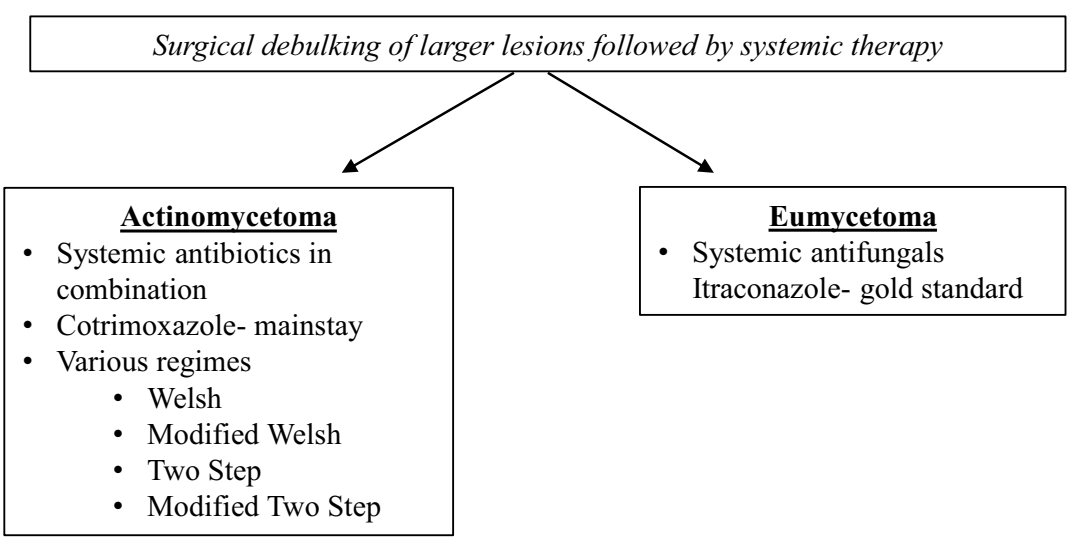

\section{$\underline{\text { Unusual presentations }}$}

- Verrucous plaque

- Painless swelling without discharging sinuses

- Abscess
- Lobulated cystic swelling

Figure 2 Summary of salient points of clinical features and treatment of mycetoma.

against Madurella mycetomatis and are not used. ${ }^{1}$ However, insertion of amphotericin B-impregnated absorbable calcium sulfate beads (Stimulan) into the 
Table 3 Various Treatment Regimes Used in Actinomycetoma

\begin{tabular}{|c|c|c|c|}
\hline Regimen & Year & Intensive Phase & Maintenance Phase \\
\hline $\begin{array}{l}\text { I. Welsh } \\
\text { regimen }\end{array}$ & & $\begin{array}{l}\text { Amikacin } 15 \mathrm{mg} / \mathrm{kg} \mathrm{IM} \mathrm{divided} \mathrm{into} \mathrm{two} \mathrm{doses}+ \\
\text { sulfamethoxazole }(35 \mathrm{mg} / \mathrm{kg} / \text { day }) \text { and trimethoprim }(7 \mathrm{mg} / \\
\mathrm{kg} / \text { day }) \text { divided into three doses for } 21 \text { days. ( } 1-3 \text { such } \\
\text { cycles at } 15 \text {-day intervals) }\end{array}$ & $\begin{array}{l}\text { Trimethoprim and sulfamethoxazole ( } 7 \text { and } 35 \mathrm{mg} / \mathrm{kg} / \text { day, } \\
\text { respectively) continuing for } 2 \text { weeks after the last cycle }\end{array}$ \\
\hline $\begin{array}{l}\text { 2. Modified } \\
\text { Welsh regimen }\end{array}$ & 2008 & $\begin{array}{l}\text { Amikacin } 15 \mathrm{mg} / \mathrm{kg} / \text { day in two divided doses }+ \\
\text { sulfamethoxazole-trimethoprim tablets }(35+7 \mathrm{mg} / \mathrm{kg} / \\
\text { day })+ \text { capsule rifampicin } 10 \mathrm{mg} / \mathrm{kg} / \text { day for } 21 \text { days; } 1-3 \\
\text { cycles at } 15 \text { day intervals }\end{array}$ & $\begin{array}{l}\text { Sulfamethoxazole-trimethoprim tablets }(35+7 \mathrm{mg} / \mathrm{kg} / \\
\text { day }+ \text { capsule rifampicin } 10 \mathrm{mg} / \mathrm{kg} / \text { day for } 3 \text { months }\end{array}$ \\
\hline $\begin{array}{l}\text { 3. Two step } \\
\text { regimen } \\
\text { (Ramam regime) }\end{array}$ & 2000 & $\begin{array}{l}\text { Crystalline penicillin I MU IV every } 6 \mathrm{~h}+\text { gentamicin } \\
80 \mathrm{mg} \text { IV every } 12 \mathrm{~h}+\text { cotrimoxazole (trimethoprim- } \\
\text { sulfamethoxazole } 80 / 400 \mathrm{mg} \text { tablets; two tablets twice } \\
\text { daily for } 5-7 \text { weeks) }\end{array}$ & $\begin{array}{l}\text { Cotrimoxazole }(80 / 400 \mathrm{mg}) \text {, two tablets twice daily }+ \\
\text { amoxicillin tablets, } 500 \mathrm{mg} \text { thrice daily for } 2-5 \text { months } \\
\text { after the disease becomes inactive }\end{array}$ \\
\hline $\begin{array}{l}\text { 4. Modified } \\
\text { two-step } \\
\text { regimen }\end{array}$ & 2007 & $\begin{array}{l}\text { Gentamicin ( } 80 \mathrm{mg} \text { twice daily, IV), and cotrimoxazole } \\
\text { (two tablets of } 960 \mathrm{mg} \text { twice daily) for } 4 \text { weeks }\end{array}$ & $\begin{array}{l}\text { Doxycycline ( } 100 \mathrm{mg} \text { orally, twice daily), and } \\
\text { cotrimoxazole (two tablets of } 960 \mathrm{mg} \text { twice daily), until } \\
\text { 5-6 months after complete healing of all sinuses. }\end{array}$ \\
\hline
\end{tabular}

Note: Data from Relhan et al.'

\section{Recommendations to Improve Currently Available Treatments in Eumycetoma}

Though the search for newer and more effective drugs for eumycetoma is going on, the response to existent therapies can be enhanced for a better therapeutic result: an oral solution of itraconazole in a cyclodextrin vehicle has increased oral bioavailability as compared to itraconazole capsules and may prove to be more efficacious mainly in the pediatric population. ${ }^{13}$ Also, effective and safe serum levels of certain drugs like itraconazole can be achieved via therapeutic drug monitoring (TDM) techniques such as high-performance liquid chromatography (HPLC) and mass spectrometry (MS). ${ }^{13}$ Addition of NSAIDs with systemic antifungals has shown good clinical outcome in refractory mycetoma (duration $>20$ years) with no relapse during 8 years of follow-up. ${ }^{15}$ Similarly, combining oral prednisolone with antifungals and sulfamethoxazole plus trimethoprim was also reported to enhance the clinical outcome of patients without causing additional side effects. ${ }^{15}$

\section{Endpoint of Treatment}

Certain parameters can be looked upon to evaluate clinical cure in a case of mycetoma like ${ }^{1}$ -

- Normal appearance of overlying skin.
- The disappearance of swelling along with healing of sinuses.

- FNAC of the tissue showing clearance of organism and its grains.

- Ultrasonographic examination demonstrating an absence of grains and cavities.

- Radiological examination exhibiting reappearance of normal bone pattern and absence of soft tissue swelling.

\section{Predictors for Recurrence}

- Poor health education and thus a late diagnosis of the disease. ${ }^{16}$

- Long-standing disease with the scarcity of medical and health facilities.

- Positive family history.

- Size of the lesions $(>10 \mathrm{~cm})$ at the time of presentation.

- Patients with long-standing extra-pedal mycetoma.

- Elderly population with shorter duration of disease and residing in non-endemic areas. This age group has low immunity and also they are not exposed to low-grade subclinical infection leading to local disease spread and difficult surgical intervention.

- Patients with pedal mycetoma of 5-10 years duration with previous surgical excisions and positive family history. Previous surgery may lead to the spread of the organisms along different tissue planes with the 
development of fibrosis and cavitation making complete excision not feasible.

- Early stoppage of systemic antimicrobials.

- Incomplete resection and faulty debridement.

- Performing local excision under local anesthesia leads to incomplete removal and thus posing a risk of recurrence.

\section{Conclusion}

Mycetoma is a global disease and puts a significant burden on the economic as well as health-care facilities of a region. Unusual presentations are also being reported which leads to a further delay in diagnosis of the disease. Due to changes in the etiological agents in different regions, guidelines regarding the use of antimicrobials differ from one region to another. The prolonged indolent course of the disease demands a search for newer therapeutic agents which can have a shorter time for a cure, thus improving patient compliance.

\section{Disclosure}

The authors report no conflicts of interest in this work.

\section{References}

1. Relhan V, Mahajan K, Agarwal P, Garg VK. Mycetoma: an update. Indian J Dermatol. 2017;62(4):332. doi:10.4103/ijd.IJD_476_16

2. Kwon-Chung KJ, Bennett JE. Mycetoma. In: Medical Mycology. Philadelphia: Lea \&Febiger; 1992:560-593.

3. Carter HV. On a new and striking form of fungus disease principally affecting the foot and prevailing endemically in many parts of India. Trans Med Phys Soc Bombay. 1860;6:104-142.

4. Hernández-Hernández F, López-Martínez R, Méndez-Tovar LJ, Manzano-Gayosso P. Nocardia brasiliensis: in vitro and in vivo growth response to steroid sex hormones. Mycopathologia. 1995;132 (2):79-85. doi:10.1007/BF01103779
5. Méndez-Tovar LJ, de Biève C, López-Martínez R. Effects of human sex hormones on in vitro development of agents of eumycétomes. J Mycol Méd. 1991;1:141-143.

6. Verma P, Jha A. Mycetoma: reviewing a neglected disease. Clin Exp Dermatol. 2019;44(2):123-129. doi:10.1111/ced.13642

7. Fahal AH, Suliman SH, Hay R. Mycetoma: the spectrum of clinical presentation. Trop Med Infect Dis. 2018;3(3):97. doi:10.3390/ tropicalmed3030097

8. Grover A, Nagaraj P, Joseph VM, Gadi D. Unusual presentation of mycetoma of the foot: a rare case report. J Orthop Case Rep. 2017;7 (1): 12 .

9. Sow D, Ndiaye M, Sarr L, et al. Mycetoma epidemiology, diagnosis management, and outcome in three hospital centres in Senegal from 2008 to 2018. PLoS One. 2020;15(4):e0231871. doi:10.1371/journal. pone. 0231871

10. Sardana K, Chugh S. Newer therapeutic modalities for Actinomycetoma by Nocardia species. Int J Dermatol. 2018;57(9): e64-e65. doi:10.1111/ijd.14073

11. Reis CM, Reis-Filho EG. Mycetomas: an epidemiological, etiological, clinical, laboratory and therapeutic review. An Bras Dermatol. 2018;93(1):8-18. doi:10.1590/abd1806-4841.20187075

12. Suleiman SH, Wadaella ES, Fahal AH. The surgical treatment of mycetoma. PLoS Negl Trop Dis. 2016;10(6):e0004690. doi:10.1371/ journal.pntd.0004690

13. Elkheir LY, Haroun R, Mohamed MA, Fahal AH. Madurellamycetomatis causing eumycetoma medical treatment: the challenges and prospects. PLoS Negl Trop Dis. 2020;14(8):e0008307. doi:10.1371/journal.pntd.0008307

14. Lalchandani R, Salvi BV, D'souza P, Gugnani HC. Successful limb salvage in a case of advanced long-standing eumycetoma of the foot using adjunctive local amphotericin B delivery through bioabsorbable beads. Indian J Orthop. 2020:1-4.

15. Dupont B, Datry A, Poirée S, Canestri A, Boucheneb S, Fourniols E. Role of a NSAID in the apparent cure of a fungal mycetoma. J Mycol Med. 2016;26:86-93. doi:10.1016/j.mycmed. 2016.03.003

16. Wadal A, Elhassan TA, Zein HA, Abdel-Rahman ME, Fahal AH. Predictors of post-operative mycetoma recurrence using machine-learning algorithms: the Mycetoma Research Center experience. PLoS Negl Trop Dis. 2016;10(10):e0005007. doi:10. 1371/journal.pntd.0005007

\section{Publish your work in this journal}

Research and Reports in Tropical Medicine is an international, peerreviewed, open access journal publishing original research, case reports, editorials, reviews and commentaries on all areas of tropical medicine, including: Diseases and medicine in tropical regions; Entomology; Epidemiology; Health economics issues; Infectious disease; Laboratory science and new technology in tropical medicine;
Parasitology; Public health medicine/health care policy in tropical regions; and Microbiology. The manuscript management system is completely online and includes a very quick and fair peer-review system. Visit http://www.dovepress.com/testimonials.php to read real quotes from published authors. 